\title{
44. PORE-WATER INDICATIONS FOR THE OCCURRENCE OF GAS HYDRATES IN EASTERN MEDITERRANEAN MUD DOME STRUCTURES ${ }^{1}$
}

\author{
Gert J. De Lange² and H.-J. Brumsack ${ }^{3}$
}

\begin{abstract}
Two mud dome structures were sampled during Leg 160 to the Eastern Mediterranean. Pore waters from the Milano Dome indicate the presence of gas hydrates at relatively shallow depths in the sediment. The deep pore waters of the Napoli Dome indicate that gas hydrates are unlikely to be present $>1$ meter below seafloor (mbsf), whereas some observations from very shallow pore waters suggest that some gas hydrates must also be present $<1 \mathrm{mbsf}$. In the case of Milano Dome, a massive cap of gas hydrates probably overlies natural gas that cannot escape because of this cap and its shape. Some of the mud-dome pore-water results of Ocean Drilling Program Leg 160 to the Eastern Mediterranean are discussed here in relation to the inferred presence of gas hydrates.
\end{abstract}

\section{INTRODUCTION}

The presence of gas hydrates in oceanic sediments was first postulated on the basis of seismic observations (e.g., Tucholke et al., 1977). It soon appeared that vast amounts of gas hydrates must occur in sediments of continental slopes and rises, if the bottom-simulating reflector (BSR) and the commonly underlying acoustic transparent layer were to be attributed to gas hydrates and underlying gascharged sediments (Shipley et al., 1979).

On the basis of BSR depth and the experimentally determined stability field for gas hydrates, thermal gradients for deep-sea sediments have been estimated (e.g., Shipley et al., 1979; Yamano et al., 1982; Kvenvolden and McMenamin, 1980; de Roo et al., 1983; Kvenvolden and Kastner, 1990; Hyndman et al., 1992). The stability field of gas hydrates appears to depend not only on pressure (water + sediment depth) and temperature, but also on the chemical composition of the gas hydrates and on the salinity of the pore water.

Methane hydrate dissociation in seawater appears to occur at a temperature that is $\sim 1^{\circ} \mathrm{C}$ lower than dissociation in pure water, whereas that in nearly NaCl-saturated water is $5^{\circ} \mathrm{C}$ lower (de Roo et al., 1983; Dickens and Quinby-Hunt, 1994). These experiments appeared to closely follow the stability conditions predicted by thermodynamic calculations (e.g., van der Waals and Platteeuw, 1959).

Pure and fully saturated methane hydrate has an average composition of $\mathrm{CH}_{4} \cdot 5.75 \mathrm{H}_{2} \mathrm{O}$. Upon disintegration, the volumetric ratio of methane to water is 164 (Davidson et al., 1978; Kvenvolden and Kastner, 1990).

Although some disagreement exists in the literature (Miller, 1974; Makogon, 1981; Handa, 1990), a large amount and a high supply rate of methane are probably needed to form gas hydrates because methane concentrations must exceed the solubility level at the in situ porewater conditions (i.e., must exceed a concentration of a few tenths of a mol/L; Ginsburg, 1996; Kvenvolden, 1996). The conditions of a sufficiently high pore-water methane concentration can be met during at least two typical situations: (1) a supply of organic matter that is sufficiently large to generate enhanced methanogenic decomposi-

${ }^{1}$ Robertson, A.H.F., Emeis, K.-C., Richter, C., and Camerlenghi, A. (Eds.), 1998. Proc. ODP, Sci. Results, 160: College Station, TX (Ocean Drilling Program).

${ }^{2}$ Utrecht University, Institute of Earth Sciences, Department of Geochemistry, Budapestlaan 4, 3584 CD Utrecht, The Netherlands. gdelange@EARTH.RUU.NL

${ }^{3}$ Oldenburg University, Institute of Chemistry and Biology of the Ocean, Postbox 2503, D-26111 Oldenburg, Federal Republic of Germany. tion of organic matter in the sediment (e.g., Peru Margin); and (2) a large upward methane flux often related to fault zones or other conduits, such as diapirs or mud volcanism (Deep Sea Drilling Project [DSDP] Legs 67, 76, 96; Ocean Drilling Program [ODP] Legs 127, 146, 160, and 164; Black Sea and Eastern Mediterranean). The methane from the first source is biogenic, whereas that from the second source is mainly thermogenic to mainly biogenic. The different origins are reflected in their stable isotope composition and in the ratio of methane to ethane + propane $(\mathrm{C} 1 /[\mathrm{C} 1+\mathrm{C} 2])$. If $\delta^{13} \mathrm{C}-\mathrm{CH}_{4}$ is less than $-60 \%$ and the $\mathrm{C} 1 /(\mathrm{C} 1+\mathrm{C} 2)$ ratio is greater than 1000 , the origin is postulated to be biogenic, whereas a $\delta^{13} \mathrm{C}-\mathrm{CH}_{4}$ greater than $-60 \%$ o and a $\mathrm{C} 1 /(\mathrm{C} 1+\mathrm{C} 2)$ ratio $<1000$ indicates a thermogenic origin (Pflaum et al., 1985).

One of the first reported observations of gas hydrates in marine sediments was from the Black Sea (Yefremova and Zhizhchenko, 1974; Brooks et al., 1985). The first observations of gas hydrates, and of indirect evidence for the initial presence of gas hydrates, were in sediments recovered by DSDP during Legs 66 and 67 in the Middle America Trench (e.g., Harrison et al., 1982; Hesse and Harrison, 1981). During several subsequent legs, the initial presence of gas hydrates was postulated in a similar way (DSDP Legs 84 and 96, ODP Legs 112, 127, 131, 146, 160, and 164). Leg 164 to the Blake Ridge was devoted to gas hydrates (Shipboard Scientific Party [ODP Leg 164], 1996); gas hydrates were mainly dispersed and occupied a few percent of the pore space.

\section{Gas Hydrates}

Studies of deep-sea gas hydrates have been seriously hampered by difficulties in recovering gas hydrates because of their instability at sea-level conditions (Fig. 1). Furthermore, gas hydrates mostly occur at depths in the sediment that are beyond the reach of normal gravity and piston coring. Thus, most reports of the occurrence and composition of gas hydrates have come from ODP research efforts.

Gas hydrates are commonly found (or inferred) to be dispersed in the sediments, which makes their recovery extremely difficult because of their rapid disintegration upon retrieval from the bottom. The high-pressure/low-temperature stability field further complicates the proper preservation and analysis of the samples.

If corrected for air contamination, all reported analyses indicate that usually $>99 \%$ of the "encaged" gas is methane, and that the $\delta^{18} \mathrm{O}$ of the "cage" water is $\sim+2.5 \%$ o. 


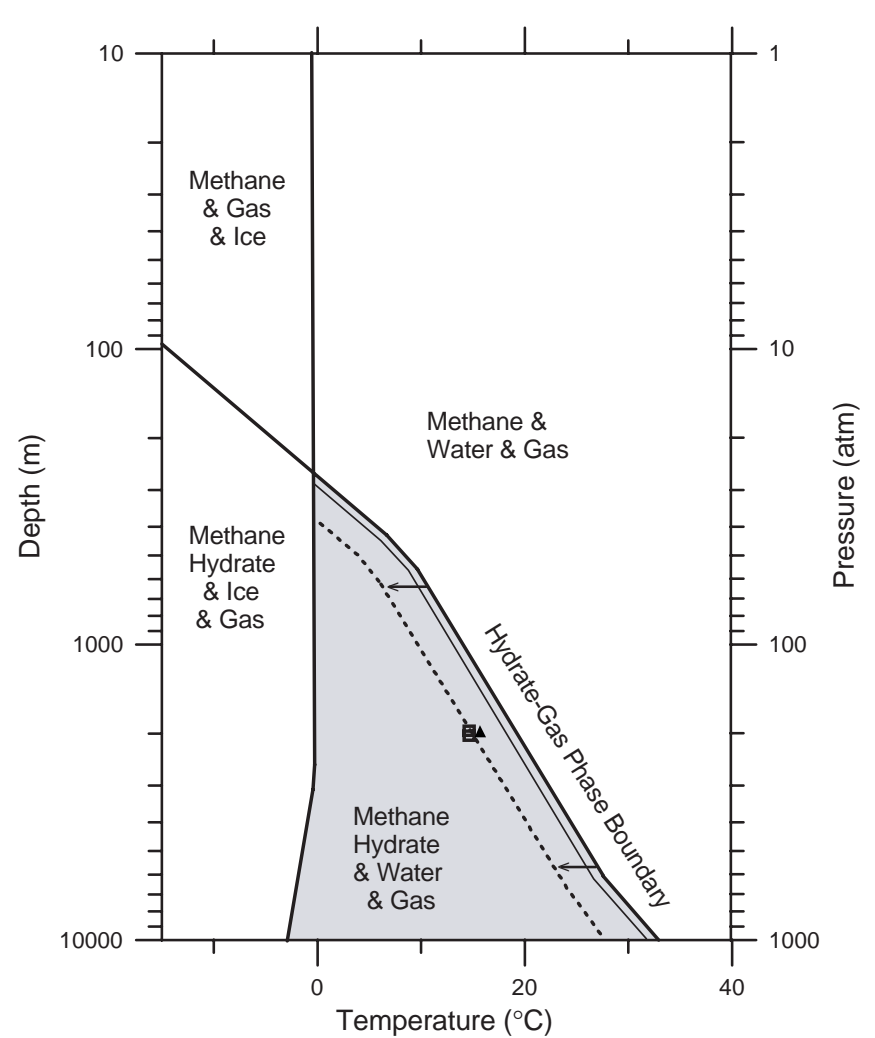

Figure 1. Phase boundary diagram demonstrating the gas hydrate/freshwater stability field in gray. Boundaries are given for the pure-methane/pure-water system. Redrawn after Kvenvolden and McDonald (1985). Directions of hydrate-gas phase boundary shift towards stabilities at higher salinities are indicated by arrows (see text). The thin line and dashed line parallel to the freshwater hydrate-gas phase boundary indicate the seawater hydrate-gas phase boundary and the brine hydrate-gas phase boundary, respectively (after Hesse and Harrison, 1981, and de Roo et al., 1983). The brine line is for a 5$\mathrm{M} \mathrm{Cl}^{-}$solution, comparable to the one assumed for the brine in this study. The open squares and solid triangle indicate the depth/temperature position for crestal sites of, respectively, sediments with inferred presence of gas hydrates at Milano Dome mud volcano and sediments with inferred absence of gas hydrates at Napoli Dome, Eastern Mediterranean. Plotted values are for $10 \mathrm{mbsf}$ depth at all sites; the two Napoli Dome sites have nearly identical depth and temperature, and consequently coincide.

\section{Initial Presence of Gas Hydrates}

The pronounced decrease in pore-water salinity has commonly been interpreted as a good indication of the initial occurrence of gas hydrates in the recovered sediments (Harrison et al., 1982).

During their formation, gas hydrates not only consume vast amounts of methane, but also extract pure water with a relatively enhanced ${ }^{18} \mathrm{O}$ content from the pore water (Davidson et al., 1983). As a consequence, the remaining pore water is more saline and is slightly depleted in $\delta^{18} \mathrm{O}$. Along the concentration gradient, salinity diffuses to overlying (and underlying) sediment intervals that do not contain gas hydrates. Upon recovery and subsequent disintegration of the gas hydrates, the pore water in the intervals with initial gas hydrates will demonstrate a decreased chlorinity and enhanced levels of $\delta^{18} \mathrm{O}$, whereas in the overlying intervals pore water should have an increased chlorinity and lower levels of $\delta^{18} \mathrm{O}$.

However, not all of the pore-water salinity gradients that decrease with depth can be attributed to the dissolution of gas hydrates during recovery. Decreases may also result from mineral dehydration upon increasing pressure, membrane filtration, dewatering of subducting sediment, input of meteoric waters, and from the deposition of a brackish near coastal sediment "slab" into the deep sea (Kvenvolden and Kastner, 1990; De Lange, 1983, and references therein). Therefore, additional confirmation is needed by alternative analyses and observations of pore-water constituents such as methane content, and $\delta^{18} \mathrm{O}$. Furthermore, the chlorinity in the pore water overlying the interval of inferred gas hydrate content should be enhanced over that in the bottom water (see above). Examples of this have been reported by Kvenvolden and Kastner (1990, fig. 6). In contrast, Harrison et al. (1982) were unable to detect such increased salinity, whereas they clearly demonstrated the initial presence of gas hydrates on the basis of their pore-water chlorinity and $\delta^{18} \mathrm{O}$ values. It is possible that only enhanced rates of gas hydrate formation may lead to discernible enhanced levels of the pore-water chlorinity in the overlying sediments.

Most of the gas hydrate findings have been reported on the basis of pore-water composition. A a decrease in the pore-water salinity is one of the more often used diagnostic tools.

\section{MATERIALS AND METHODS}

Pore waters for Sites 970 and 971 were extracted and analyzed by routine ODP methods (Gieskes et al., 1991), whereas those for cores ND2A, MT3A, and KC11 were done by shipboard routine and analytical methods described previously (De Lange, 1986, 1992; Van Santvoort et al., 1996).

\section{RESULTS AND DISCUSSION}

During Leg 160 to the Eastern Mediterranean, two different mud domes (Milano and Napoli Domes) were drilled on the margin of the Mediterranean Ridge. The Milano Dome seems to be inactive at present, whereas Napoli Dome shows evidence of recent gas, fluid, and mud flows (e.g., Robertson et al., 1996). The salinity of interstitial waters ranges from brackish to brine, and the solid phase is mainly breccia (De Lange et al., 1996; Emeis, Robertson, Richter, et al., 1996). A clear difference exists between the recovered pore waters of Milano Dome and Napoli Dome crest sites, the former being brackish and the latter brine-like (Figs. 2, 3, 4).

The enhanced salinity at Napoli Dome sites is almost entirely caused by an increase in dissolved halite content $(\mathrm{NaCl})$. The Napoli Dome brine is, therefore, likely to be associated with early stage evaporites or "relic" brines (De Lange et al., 1990; Vengosh et al., unpubl. data). In fact, halite crystals and crusts have been found in some of the sediments of Napoli Dome (Robertson et al., 1996). Results from pore waters in previously recovered Napoli Dome crestal sediments in box cores ND2A and MT3A, and in piston core KC11 correspond nicely with those from Holes 971D and 971E for most elements (not shown in figure).

The presence of low-salinity waters at Milano Dome is unlikely to be related to the expulsion of low-salinity waters from sources deeper downhole, because most sediments of the Mediterranean seafloor are underlain by Messinian evaporites. Consequently, at most sites in the Eastern Mediterranean, steep increases in salinity vs. depth have been found (Van Santvoort and De Lange, 1996). The strong brine influence (i.e., increase in salinity vs. depth) can be observed in the noncrestal sites from the Napoli and Milano Domes (Figs. 2, 3). The correspondence between the noncrestal sites indicates that the pore waters in both mud domes are brine-dominated. In the crestal sites, however, the pore waters appear to be "freshwater"dominated at Milano Dome, whereas they are brine-dominated at Napoli Dome. If the brackish pore waters at Milano Dome were to result from the simple mixing of freshwater and seawater, then the element/chloride ratio would not deviate from that of seawater. A major 


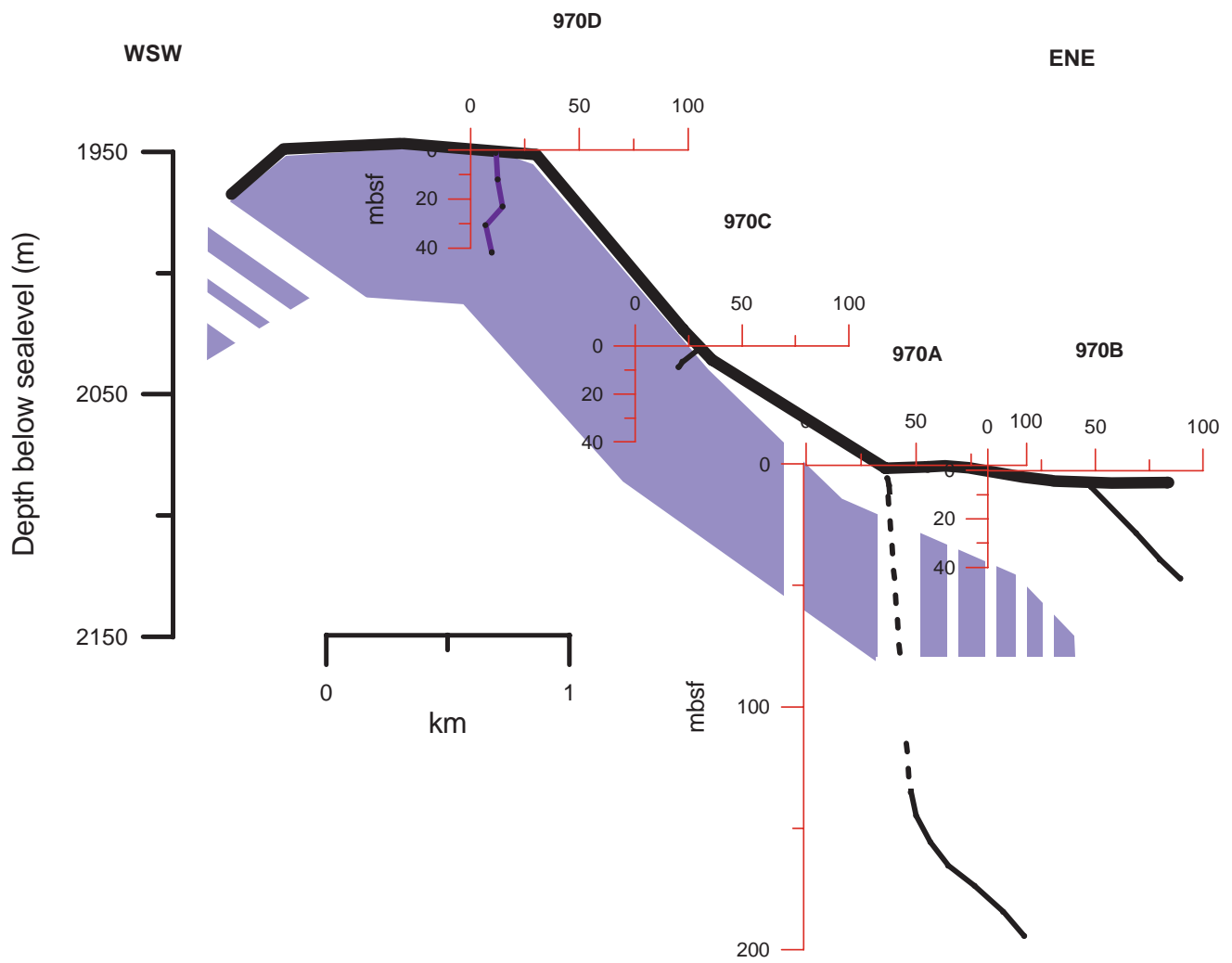

Figure 2. Cross section of Milano Dome site, Eastern Mediterranean. Salinity profiles are shown at the approximate positions relative to the dome structure. The gray area indicates gas hydrate occurrence as inferred from pore-water data (see text). Bottom-water salinity is $38 \%$.

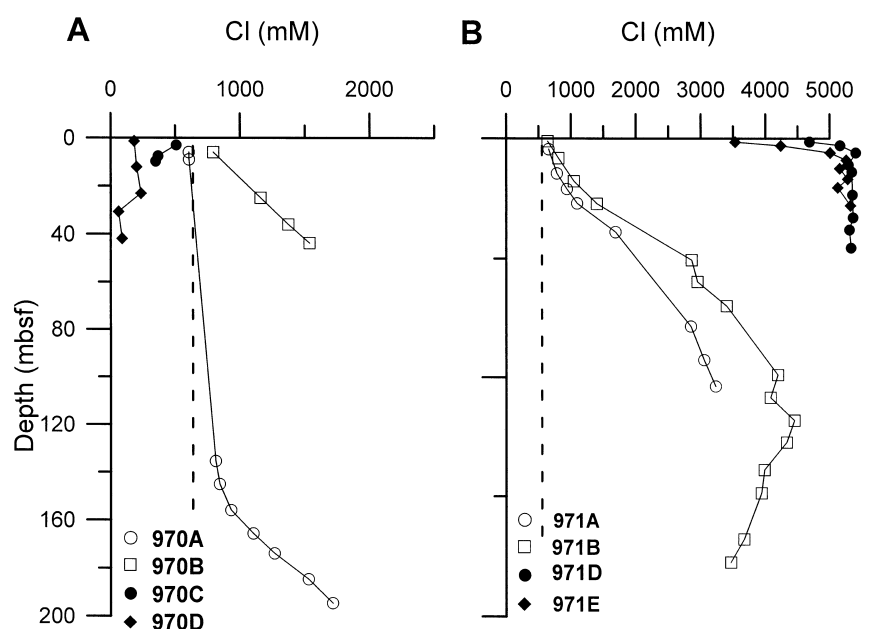

Figure 3. Pore-water chloride profiles for the four sites at (A) Milano Dome, and (B) Napoli Dome; bottom-water chloride content is indicated by the dashed line.

deviation from seawater occurs for the $\mathrm{K} / \mathrm{Cl}$ ratio in Holes $970 \mathrm{C}$ and 970D. Moreover, the element/chloride ratios in the pore waters at Milano Dome indicate a NaCl-brine dominance, in excellent agreement with those at Napoli Dome (Table 1). It seems, therefore, that the low salinities in the pore waters at Milano Dome are caused by the presence of significant amounts of methane hydrates in combination with brine-dominated in situ pore waters. This option is strongly supported by the abundant presence of gas, and obvious core expansion fea-

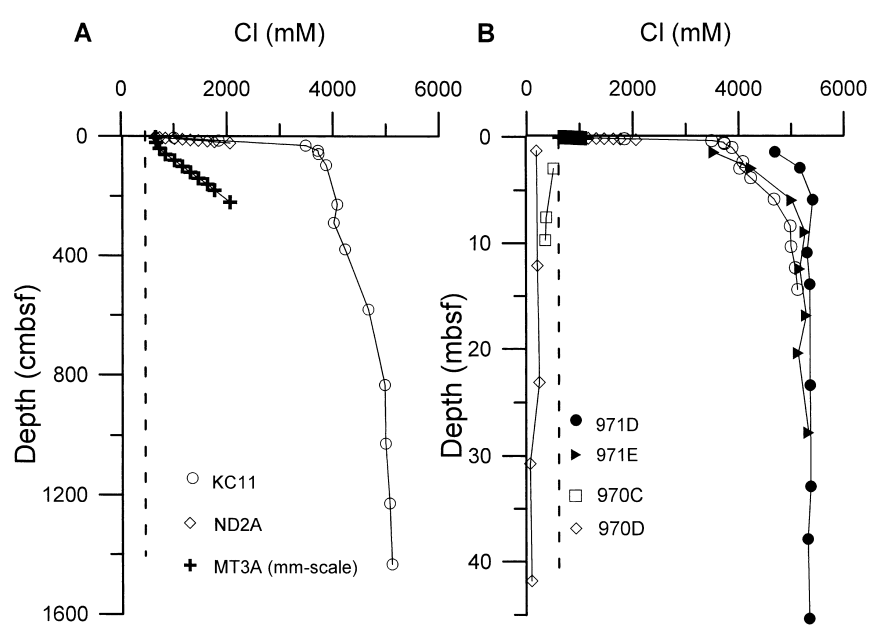

Figure 4. Pore-water chloride profiles for (A) box cores ND2A and MT3A, and piston core KC11 (both at Napoli Dome crest), and (B) Holes 970C and 970D (at Milano Dome crest), box cores ND2A and MT3A, piston core KC11, and Holes 971D and 971E (all at Napoli Dome crest). Please, note the difference in depth scales: most of the data in A are plotted in centimeters, whereas the MT3A data are plotted in millimeters below seafloor; the data in $\mathrm{B}$ are plotted in meters below seafloor. The dashed line indicates bottomwater concentration.

tures, such as numerous gas pockets and the rupture of the core liner of Core 160-970D-2H. The gas appeared to be nearly pure methane (Emeis, Robertson, Richter, et al., 1996; see also Rullkötter et al., 
Chap. 22, this volume). The significant change in element/chloride ratio in the pore waters from Holes 971D (Napoli Dome) and 970D (Milano Dome) can be evaluated with respect to a two-end-member mixing of seawater and brine. $\mathrm{As} \mathrm{Mg}, \mathrm{Ca}$, and $\mathrm{Sr}$ are involved in carbonate precipitation and recrystallization reactions, and as the $\mathrm{Na} / \mathrm{Cl}$ ratio of seawater and brine is rather similar ( 0.86 vs. 1$)$, all of these elements are not particularly suitable for such evaluation. Although not entirely free of diagenetic changes, $\mathrm{K}$ seems to be the best choice of element for such evaluation at this moment (Fig. 5). In view of the time scales, temperatures, depth ranges, and shift in $\mathrm{K}$ relative to $\mathrm{Cl}$ content involved, a possible diagenetic decrease of $\mathrm{K}$ with depth would have only minor influence on the estimations made below. If a simple two-end-member calculation is done for the $\mathrm{K} / \mathrm{Cl}$ ratio in the pore waters of Napoli Dome and Milano Dome (Holes 971D and 970D), then the average contribution of seawater and brine can be estimated. In this calculation, we assume that the composition of the brine at Milano Dome is similar to that at Napoli Dome. The Napoli Dome brine being NaCl-dominated, this assumption is likely to lead to an underestimation of the Milano Dome brine contribution, if the initial Milano Dome brine were to contain a slightly higher K concentration than the Napoli Dome brine. Consequently, the calculated brine contributions are likely to be underestimated. The $\mathrm{K} / \mathrm{Cl}$ ratio of end members considered in this calculation are $0.020,0.0030$, and $0.0010(\mathrm{M} / \mathrm{M})$ for seawater, Milano Dome pore water, and Napoli Dome brine respectively. The resulting brine contribution to the interstitial waters of Milano Dome is thus estimated to be $>85 \%$.

Although gas hydrates were not recovered at Milano Dome, they are likely to occur close to the sediment/water interface in Hole $970 D$. Salinity values as low as $7 \%$ can be explained only by a contribution to the pore-water pool of at least $80 \%$ hydrate water and of $<20 \%$ pore water of "normal" Mediterranean bottom water with a salinity of $38 \%$. This proportion of gas hydrate-related water is a minimum value, as the remaining in situ pore fluid is likely to be brine rather than seawater (see above). In addition, the position of the Milano Dome gas hydrate occurrence in the pressure/temperature stability plot further supports this view (see above; Fig. 1; de Roo et al., 1983). If the minimum brine contribution of $85 \%$ is adopted, it follows that $<2 \%$ of the observed interstitial water may actually have been present in situ, whereas $>98 \%$ of the observed pore water must originate from disintegration of gas hydrates upon recovery.

Sulfate is essentially absent below $1.3 \mathrm{mbsf}$, and alkalinity values of $>70 \mathrm{mM}$ reflect the bacterial consumption of methane. The formation of methane hydrates near the sediment/water interface seems to be related to the high supply rate of methane by emanating fluids, the pressure (water depth) and temperature of the bottom water $\left(14.2^{\circ} \mathrm{C}\right)$, and the availability of pore space (mud breccia; Emeis, Robertson, Richter, et al., 1996). All these prerequisites are found at Hole 970D and possibly at Hole 970C, and are compatible with the stability field of methane gas hydrates.

Recently, the massive occurrence of gas hydrates at relatively shallow sediment depths (up to a few meters) in mud volcano-related sediments of the Eastern Mediterranean and Black Sea have been
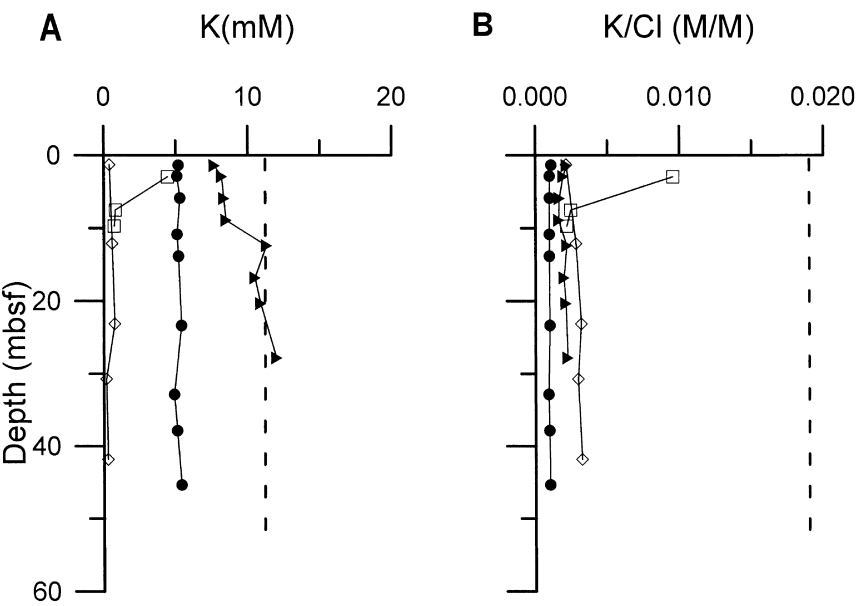

Figure 5. Pore-water concentrations for the crestal sites of Napoli Dome (Holes 971D and 971E) and Milano Dome (Holes 970C and 970D) for (A) K and (B) $\mathrm{K} / \mathrm{Cl}$. The dashed line indicates seawater composition; symbols are as indicated in Figure 4B.

Table 1. Salinity, chloride, and element/chloride ratios for samples from the crestal sites of Milano Dome (Site 970) and Napoli Dome (Site 971) mud volcanoes.

\begin{tabular}{|c|c|c|c|c|c|c|c|c|c|}
\hline $\begin{array}{l}\text { Core, section, } \\
\text { interval }(\mathrm{cm})\end{array}$ & $\begin{array}{l}\text { Depth } \\
\text { (mbsf) }\end{array}$ & $\begin{array}{c}\text { Salinity } \\
(\mathrm{g} / \mathrm{kg})\end{array}$ & $\begin{array}{c}\mathrm{Cl} \\
(\mathrm{mM})\end{array}$ & $\begin{array}{l}\mathrm{Na} / \mathrm{Cl} \\
(\mathrm{M} / \mathrm{M})\end{array}$ & $\begin{array}{l}\mathrm{Mg} / \mathrm{Cl} \\
(\mathrm{M} / \mathrm{M})\end{array}$ & $\begin{array}{c}\mathrm{K} / \mathrm{Cl} \\
(\mathrm{M} / \mathrm{M})\end{array}$ & $\begin{array}{l}\mathrm{Ca} / \mathrm{Cl} \\
(\mathrm{M} / \mathrm{M})\end{array}$ & $\begin{array}{l}\mathrm{SO}_{4} / \mathrm{Cl} \\
(\mathrm{M} / \mathrm{M})\end{array}$ & $\begin{array}{c}\mathrm{Li} / \mathrm{Cl} \\
(\mathrm{mM} / \mathrm{M})\end{array}$ \\
\hline \multicolumn{10}{|l|}{ 160-970C- } \\
\hline $1 \mathrm{H}-2,145-150$ & 2.95 & 28.7 & 509 & 0.99 & 0.0403 & 0.0096 & 0.0035 & 0.0014 & 0.090 \\
\hline $2 \mathrm{H}-2,132-142$ & 7.52 & 22.0 & 369 & 1.13 & 0.0072 & 0.0025 & 0.0018 & 0.0016 & 0.089 \\
\hline $3 \mathrm{H}-2,0-10$ & 9.70 & 20.3 & 350 & 1.11 & 0.0059 & 0.0022 & 0.0015 & 0.0017 & 0.095 \\
\hline \multicolumn{10}{|l|}{ 160-970D- } \\
\hline $1 \mathrm{H}-1,127-150$ & 1.27 & 11.7 & 183 & 1.06 & 0.0085 & 0.0022 & 0.0023 & 0.0043 & 0.093 \\
\hline $2 \mathrm{H}-5,130-150$ & 12.1 & 12.5 & 202 & 1.01 & 0.0059 & 0.0028 & 0.0025 & 0.0011 & 0.114 \\
\hline $3 \mathrm{H}-6,130-150$ & 23.1 & 14.8 & 236 & 1.06 & 0.0072 & 0.0032 & 0.0000 & 0.0013 & 0.121 \\
\hline $4 \mathrm{H}-5,130-150$ & 30.71 & 7.0 & 61 & 1.92 & 0.0115 & 0.0030 & 0.0000 & 0.0018 & 0.270 \\
\hline $5 \mathrm{H}-6,130-150$ & 41.8 & 9.8 & 88 & 1.66 & 0.0068 & 0.0032 & 0.0000 & 0.0051 & 0.182 \\
\hline \multicolumn{10}{|l|}{ 160-971D- } \\
\hline $1 \mathrm{H}-1,135-150$ & 1.35 & 258 & 3827 & 0.78 & 0.0007 & 0.0011 & 0.0009 & 0.0027 & 0.038 \\
\hline $1 \mathrm{H}-2,135-150$ & 2.85 & 282 & 4140 & 0.82 & 0.0008 & 0.0010 & 0.0023 & 0.0032 & 0.038 \\
\hline $1 \mathrm{H}-4,135-150$ & 5.85 & 293 & 4167 & 0.78 & 0.0008 & 0.0010 & 0.0091 & 0.0028 & 0.037 \\
\hline $2 \mathrm{H}-2,135-150$ & 10.85 & 292 & 4129 & 0.82 & 0.0004 & 0.0010 & 0.0019 & 0.0025 & 0.036 \\
\hline $2 \mathrm{H}-4,135-150$ & 13.85 & 295 & 4147 & 0.77 & 0.0002 & 0.0010 & 0.0012 & 0.0026 & 0.034 \\
\hline $3 \mathrm{H}-4,135-150$ & 23.35 & 297 & 4083 & 0.74 & 0.0000 & 0.0010 & 0.0001 & 0.0026 & 0.034 \\
\hline $4 \mathrm{H}-4,135-150$ & 32.85 & 300 & 4128 & $(0.80)$ & 0.0001 & 0.0009 & 0.0010 & 0.0022 & 0.034 \\
\hline $5 \mathrm{H}-1,135-150$ & 37.85 & 297 & 4145 & 0.78 & 0.0007 & 0.0010 & 0.0004 & 0.0028 & 0.032 \\
\hline $5 \mathrm{H}-6,135-150$ & 45.35 & 298 & 4074 & 0.80 & 0.0000 & 0.0010 & 0.0000 & 0.0024 & 0.027 \\
\hline \multicolumn{10}{|l|}{ 160-971E- } \\
\hline $1 \mathrm{H}-1,140-150$ & 1.4 & 200 & 3535 & 0.87 & 0.0015 & 0.0022 & 0.0004 & 0.0054 & 0.047 \\
\hline $1 \mathrm{H}-2,140-150$ & 2.9 & 238 & 4242 & 0.82 & 0.0009 & 0.0019 & 0.0002 & 0.0055 & 0.045 \\
\hline $1 \mathrm{H}-4,140-150$ & 5.9 & 278 & 5010 & 0.81 & 0.0005 & 0.0017 & 0.0001 & 0.0057 & 0.045 \\
\hline $1 \mathrm{H}-6,140-150$ & 8.9 & 295 & 5260 & 0.78 & 0.0004 & 0.0016 & 0.0000 & 0.0056 & 0.044 \\
\hline $2 \mathrm{H}-2,140-150$ & 12.4 & 283 & 5158 & 0.79 & 0.0001 & 0.0022 & 0.0000 & 0.0054 & 0.045 \\
\hline $2 \mathrm{H}-5,130-140$ & 16.8 & 293 & 5281 & 0.76 & 0.0001 & 0.0020 & 0.0000 & 0.0031 & 0.042 \\
\hline $3 \mathrm{H}-1,135-150$ & 20.35 & 282 & 5128 & 0.77 & 0.0002 & 0.0021 & 0.0000 & 0.0051 & 0.042 \\
\hline $3 \mathrm{H}-7,69-84$ & 27.81 & 300 & 5325 & 0.77 & 0.0000 & 0.0023 & 0.0000 & 0.0059 & 0.039 \\
\hline \multicolumn{2}{|l|}{ Seawater } & 35 & 559 & 0.86 & 0.097 & 0.019 & 0.019 & 0.052 & 0.048 \\
\hline
\end{tabular}




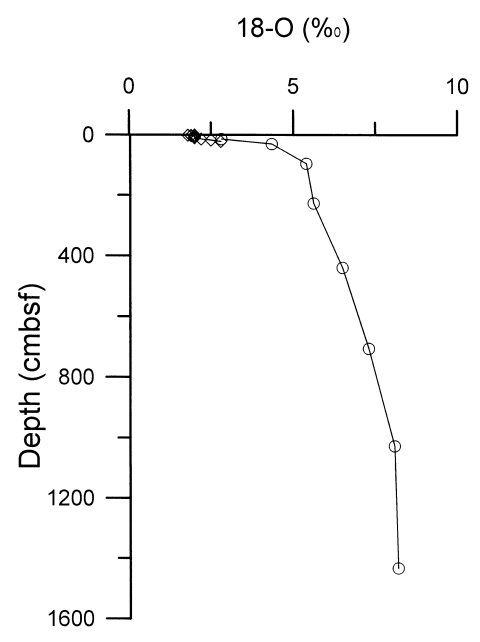

Figure 6. Oxygen isotopic composition of the pore water at Napoli Dome; symbols are as indicated in Figure 4A.

confirmed (Woodside and Ivanov, pers. comm., 1996; Woodside et al., 1996).

\section{Gas Hydrates at Milano Dome vs. Napoli Dome}

The presence of gas hydrates is evident in the sediments of Milano Dome, whereas they seem to be absent from the deep sediments of the nearby Napoli Dome. The sediment temperature at Napoli Dome crest is slightly $\left(2^{\circ} \mathrm{C}\right)$ higher than the bottom water (Leg 160). At these sites, the in situ conditions for depth, salinity, and temperature are close to the stability boundary for gas hydrates (Fig. 1). Consequently, the slightly higher, within-sediment temperature at Napoli Dome relative to that at Milano Dome seems to be the factor controlling the presence or absence of gas hydrates at these sites.

The relatively heavy $\delta^{18} \mathrm{O}$ of pore water and carbonate crust, as well as the low $\delta^{13} \mathrm{C}$ of this crust $(-24.7 \%$ o relative to $\sim-22 \%$ for organic matter) found at the Napoli Dome crest are indications for the shallow presence of gas hydrates ( $<1 \mathrm{mbsf}$ ) and for a possible (deep) regeneration of gas hydrates, which may produce "heavy" water (Fig. 6), and large amounts of methane (Rullkötter et al., Chap. 22, this volume). This could be one of the possible ways of initiating mud volcano formation.

\section{CONCLUSIONS}

Eastern Mediterranean mud dome structures seem to be associated with the presence of a large amount of natural gas, methane. In the now dormant Milano Dome this has led to the massive occurrence of gas hydrates at relatively shallow depth in the sediment (from 1 to $>40$ mbsf). In the active Napoli Dome, no gas hydrates seem to occur in the sediments recovered during Leg 160 (i.e., from 1.4 to $45 \mathrm{mbsf}$ ). The pore-water major element and isotopic composition for box cores ND2A and MT3A, piston core KC11, and Holes 971D and 971E, however, suggest the very shallow ( $<1 \mathrm{mbsf}$ ) occurrence of gas hydrates and the possible deep regeneration of gas hydrates at this site.

\section{ACKNOWLEDGMENTS}

All Leg 160 participants are thanked for their cooperation, but we thank in particular A. Pimmel, R. Kemp, J. Rullkötter, and I. Bouloubassi. We acknowledge G. Ginsburg, V. Soloviev, A. Camerlenghi, and an anonymous reviewer for their thorough reviews. GDL ac- knowledges the financial support from GAO/NWO by Grant 750.00.620.7290 for participation in Leg 160, and from MAST programs MAS90-0022C and MAST2-CT93-0051. H. de Waard, D. van der Meent, and A. van Dijk are thanked for their analytical assistance. This is NSG paper number 970151.

\section{REFERENCES}

Brooks, J.M., Jeffrey, A.W.A., McDonald, T.J., Pflaum, R.C., and Kvenvolden, K.A., 1985. Geochemistry of hydrate gas and water from Site 570, Deep Sea Drilling Project Leg 84. In von Huene, R., Aubouin, J., et al., Init. Repts. DSDP, 84: Washington (U.S. Govt. Printing Office), 699703.

Davidson, D.W., El-Defrawy, M.K., Fuglem, M.O., and Judge, A.S., 1978. Natural gas hydrates in northern Canada. Proc. 3rd Int. Conf. Permafrost, 3:937-943.

Davidson, D.W., Leaist, D.G., and Hesse, R., 1983. Oxygen-18 enrichment in water of a clathrate hydrate. Geochim. Cosmochim. Acta, 47:22932295.

De Lange, G.J., 1983. Geochemical evidence of a massive slide in the southern Norwegian Sea. Nature, 305:420-422. 1986. Chemical composition of interstitial waters in cores from the Nares Abyssal Plain (Western North Atlantic). Oceanol. Acta, 9:159168.

, 1992. Shipboard routine and pressure-filtration system for pore water extraction from suboxic sediments. Mar. Geol. 109:77-81.

De Lange, G.J., Brumsack, H.-J., and Shipboard Participants of Leg 160, 1996. Gas hydrates in the Eastern Mediterranean: evidence from interstitial waters recovered during Leg 160 on Milano and Napoli Dome mud volcanoes. 1st EuroColloq., Oldenburg, 2.

De Lange, G.J., Boelrijk, N.A.I.M., Catalano, G., Corselli, C., Klinkhammer, G.P., Middelburg, J.J., Mueller, D.W., Ullman, W.J., Van Gaans, P., and Woittiez, J.R.W., 1990. Sulphate-related equilibria in the hypersaline brines of the Tyro and Bannock Basins, eastern Mediterranean. Mar. Chem. 31:89-112.

de Roo, J.L., Peters, C.J., Lichtenthaler, R.N., and Diepen, G.A.M., 1983. Occurrence of methane in hydrate-bearing sediments and undersaturated solutions of sodium chloride and water in dependence of temperature and pressure. AIChE J., 29:651-657.

Dickens, G.R., and Quinby-Hunt, M.S., 1994. Methane hydrate stability in seawater. Geophys. Res. Lett., 21:2115-2118.

Emeis, K.-C., Robertson, A.H.F., Richter, C., et al., 1996. Proc. ODP, Init. Repts., 160: College Station, TX (Ocean Drilling Program).

Gieskes, J.M., Gamo, T., and Brumsack, H., 1991. Chemical methods for interstitial water analysis aboard JOIDES Resolution. ODP Tech. Note, 15.

Ginsburg, G.D., 1996. How do gas-hydrates accumulate in deep-water marine sediments: migration of hydrate-forming reactants. First Master Workshop on Gas Hydrates: Relevance to World Margin Stability and Climate Change, Gent, Belgium, 123-147.

Handa, Y.P., 1990. Effect of hydrostatic pressure and salinity on the stability of gas hydrates. J. Phys. Chem., 94:2652-2657.

Harrison, W.E., Hesse, R., and Gieskes, J.M., 1982. Relationship between sedimentary facies and interstitial water chemistry of slope, trench, and Cocos plate sites from the Middle America Trench transect, active margin off Guatemala, Deep Sea Drilling Project Leg 67. In Aubouin, J., von Huene, R., et al., Init. Repts. DSDP, 67: Washington (U.S. Govt. Printing Office), 603-614.

Hesse, R., and Harrison, W.E., 1981. Gas hydrates (clathrates) causing porewater freshening and oxygen isotope fractionation in deep-water sedimentary sections of terrigenous continental margins. Earth Planet. Sci. Lett., 55:453-462.

Hyndman, R.D., Foucher, J.P., Yamano, M., Fisher, A., Berner, U., Brückmann, W., Byrne, T., Chabernaud, T., Firth, J.V., Gamo, T., Gieskes, J.M., Hill, I.A., Karig, D.E., Kastner, M., Kato, Y., Lallemand, S., Lau, R., Maltman, A.J., Moore, G.F., Moran, K., Olafsson, G., Owens, W.H., Pickering, K., Siena, F., Taira, A., Taylor, E., Underwood, M.B., Wilkinson, C., and Zhang, J., 1992. Deep sea bottom-simulating-reflectors: calibration of the base of the hydrate stability field as used for heat flow estimates. Earth Planet. Sci. Lett., 109:289-301.

Kvenvolden, K.A., 1996. A primer on the geological occurrence of gas hydrate. First Master Workshop on Gas Hydrates: Relevance to World Margin Stability and Climate Change, Gent, Belgium, 39-80. 
Kvenvolden, K.A., and Kastner, M., 1990. Gas hydrates of the Peruvian outer continental margin. In Suess, E., von Huene, R., et al., Proc. ODP, Sci. Results, 112: College Station, TX (Ocean Drilling Program), 517-526.

Kvenvolden, K.A., and McDonald, T.J., 1985. Gas hydrates of the Middle America Trench-Deep Sea Drilling Project Leg 84. In von Huene, R., Aubouin, J., et al., Init. Repts. DSDP, 84: Washington (U.S. Govt. Printing Office), 667-682.

Kvenvolden, K.A., and McMenamin, M.A., 1980. Hydrates of natural gas: a review of their geologic occurrence. Geol. Surv. Circ. (U.S.), 825.

Makogon, Y.F., 1981. Hydrates of Natural Gas: Tulsa, OK (PennWell).

Miller, S.L., 1974. The nature and occurrence of clathrate hydrates. In Kaplan, I.R. (Ed.), Natural Gases in Marine Sediments: New York (Plenum), 151-177.

Pflaum, R.C., Brooks, J.M., Cox, H.B., Kennicutt, M.C., and Sheu, D.-D., 1986. Molecular and isotopic analysis of core gases and gas hydrates, Deep Sea Drilling Project Leg 96. In Bouma, A.H., Coleman, J.M., Meyer, A.W., et al., Init. Repts. DSDP, 96: Washington (U.S. Govt. Printing Office), 781-784.

Robertson, A., Emeis, K.-C., Richter, C., Blanc-Valleron, M.-M., Bouloubassi, I., Cramp, A., De Lange, G.J., Di Stefano, E., Flecker, R., Frankel, E., Howell, M.W., Janecek, T.R., Jurado-Rodriguez, M.-J., Kemp, A.E.S., Koizumi, I., Kopf, A., Major, C.O., Mart, Y., Pribnow, D.F.C., Rabaute, A., Roberts, A., Rullkötter, J.H., Sakamoto, T., Spezzaferri, S., Staerker, T.S., Stoner, J.S., Whiting, B.M., and Woodside, J.M., 1996. Mud volcanism on the Mediterranean Ridge-Initial results of Ocean Drilling Program Leg 160. Geology, 24:239-242.

Shipboard Scientific Party [ODP Leg 164], 1996. Methane gas hydrate drilled at Blake Ridge. Eos, 77:219.

Shipley, T.H., Houston, M.H., Buffler, R.T., Shaub, F.J., McMillen, K.J., Ladd, J.W., and Worzel, J.L., 1979. Seismic evidence for widespread pos- sible gas hydrate horizons on continental slopes and rises. AAPG Bull., 63:2204-2213.

Tucholke, B.E., Bryan, G.M., and Ewing, J.I., 1977. Gas-hydrate horizons detected in seismic-profiler data from the western North Atlantic. $A A P G$ Bull., 61:698-707.

van der Waals, J.H., and Platteeuw, J.C., 1959. Clathrate solution. $A d v$. Chem. Phys., 2:1-57.

Van Santvoort, P.J.M., and De Lange, G.J., 1996. Messinian salt fluxes into the present-day Eastern Mediterranean: implications for budget calculations and stagnation. Mar. Geol., 132:241-251.

Van Santvoort, P.J.M., de Lange, G.J., Thomson, J., Cussen, H., Wilson, T.R.S., Krom, M.D., and Ströhle, K., 1996. Active post-depositional oxidation of the most recent sapropel (S1) in sediments of the Eastern Mediterranean. Geochim. Cosmochim. Acta., 60:4007-4024.

Woodside, J.M., Ivanov, M.K., and Shipboard Scientists of the Anaxiprobe96 Expedition, 1996. Shallow gas and gas hydrates in the Anaximander Mountains region, eastern Mediterranean Sea. First Master Workshop on Gas Hydrates: Relevance to World Margin Stability and Climate Change, Gent, Belgium, 48-49.

Yamano, M., Uyeda, S., Aoki, Y., and Shipley, T.H., 1982. Estimates of heat flow derived from gas hydrates. Geology, 10:339-343.

Yefremova, A.G., and Zhizhchenko, B.P., 1974. Occurrence of crystal hydrates of gases in sediments of modern marine basins. Dokl. Akad. Nauk SSSR, Earth Sci. Sect., 214:219-220.

Date of initial receipt: 27 January 1997

Date of acceptance: 18 August 1997

Ms 160SR-042 